\title{
REVIEW
}

\section{Latitudinal gradients in Scrobicularia plana reproduction patterns, population dynamics, growth, and secondary production}

\author{
Tiago Verdelhos ${ }^{1,2, *}$, P. G. Cardoso1, M. Dolbeth ${ }^{1,2}$, M. A. Pardal ${ }^{2}$ \\ ${ }^{1}$ Institute of Marine Research (IMAR), Department of Life Sciences, University of Coimbra, 3004-517 Coimbra, Portugal \\ ${ }^{2}$ Centre for Functional Ecology (CFE), Department of Life Sciences, University of Coimbra, Apartado 3046, \\ 3001-401 Coimbra, Portugal
}

\begin{abstract}
The bivalve Scrobicularia plana is a dominant species in terms of biomass and productivity in intertidal soft-substrate benthic communities along the NE Atlantic area. As such, it constitutes an important link in the food web and as a human food source, with high commercial and economic value. Several studies have suggested the existence of latitudinal variation in the ecological patterns of the species along its geographic distribution range. In the present study, a review and a comparison among previous studies on this species were performed. The resulting patterns of reproduction, population dynamics, growth and secondary production were analysed, and possible relationships between latitude and $S$. plana's ecological patterns and life strategies assessed. Results suggest the existence of different life strategies, depending on temperature, latitudinal gradient and local habitat conditions. Higher-latitude populations usually exhibit low abundance values, shorter reproduction periods and a 'slower' lifestyle, with lower growth rates $(0.1<k<0.2$, where $k$ is a growth coefficient), extended lifespan and lower productivity. Areas between 40 and $45^{\circ} \mathrm{N}$ seem to present optimal ecological conditions, with the highest abundance values registered, longer reproduction periods, 'faster' growth $(0.3<k<0.8)$ and higher productivity, while further south, populations showed lower abundance, productivity and growth rates.
\end{abstract}

KEY WORDS: Latitude $\cdot$ Scrobicularia plana $\cdot$ Ecological patterns

\section{INTRODUCTION}

Scrobicularia plana is a long-living selective deposit-feeder bivalve that is both eurythermal and euryhaline, and inhabits intertidal soft bottoms with abundant organic matter (Hughes 1970a, Guelorget \& Mazoyer-Mayère 1983, Essink et al. 1991, Sola 1997, Guerreiro 1998, Casagranda \& Boudouresque 2005, Verdelhos et al. 2005). It is considered one of the dominant species of intertidal soft-substrate in estuaries, lagoons and bays along the NE Atlantic coast (Hughes 1970a, Bachelet 1982, Casagranda \& Boudouresque 2005, Dolbeth et al. 2005, Verdelhos et al. 2005, Cardoso et al. 2008), showing a wide geographic distribution, from Norway $\left(60^{\circ} \mathrm{N}\right)$ to the Mediterranean and West Africa $\left(14^{\circ} \mathrm{N}\right)$.

Moreover, this species is an important link in the food chains of these ecosystems, playing an important role in the diet of wading birds, crabs and benthic fish (Hughes 1969, 1970b, Bachelet 1982, Guelorget \& Mazoyer-Mayère 1983, Casagranda \& Boudouresque 2005, Langston et al. 2007). There is 
increasing commercial interest in it as a human food resource with potential economic and social value (Rodríguez-Rúa et al. 2003, Langston et al. 2007).

Scrobicularia plana studies ranging from the UK and the Wadden Sea to Tunisia have focused on reproduction (Paes-da-França 1956, Hughes 1971, Worrall et al. 1983, Sola 1997, Guerreiro 1998, Rodríguez-Rúa et al. 2003, Raleigh \& Keegan 2006, Mouneyrac et al. 2008), population dynamics (Hughes 1970a, Guelorget \& Mazoyer-Mayère 1983, Essink et al. 1991, Sola 1997, Guerreiro 1998, Casagranda \& Boudouresque 2005, Verdelhos et al. 2005), individual growth (Green 1957, Hughes 1970a, Bachelet 1981, Guelorget \& Mazoyer-Mayère 1983, Sola 1997, Guerreiro 1998, Verdelhos et al. 2005) and secondary production (Hughes 1970b, Bachelet 1982, Guelorget \& Mazoyer-Mayère 1983, Sola 1997, Guerreiro 1998, Casagranda \& Boudouresque 2005, Verdelhos et al. 2005), and these studies suggest the existence of latitudinal variations.

Latitudinal gradients for bivalves are well established, focusing either on biodiversity (Crame 2000, 2002, Rex et al. 2000, Roy et al. 2000a) or on growth rate, body size and lifespan (MacDonald \& Thompson 1988, Hummel et al. 1998, Roy et al. 2000b). However, bivalve populations seem to be influenced not by latitude per se, but by several environmental variables - e.g. temperature, seasonality, precipitation and ecosystem energy flux. These parameters co-vary with latitude and interact with each other, influencing recruitment success, survival and growth rates, controlling primary production and consequently the food supply in the ecosystem (Macpherson 2002, Willig et al. 2003, Angilletta \& Sears 2004, Giangrande \& Licciano 2004).

A general latitudinal trend in temperature is observed along the European coast, with temperature decreasing with increasing latitude (www. worldweather.org). Temperature seems to play an important role in Scrobicularia plana population dynamics, controlling reproduction patterns (Hughes 1971, Worrall et al. 1983, Sola 1997, Rodríguez-Rúa et al. 2003, Raleigh \& Keegan 2006, Mouneyrac et al. 2008), survival and mortality (Hughes 1969, Guelorget \& Mazoyer-Mayère 1983, Essink et al. 1991), growth rates (Bachelet 1981), and consequently secondary production. Different temperature patterns may then result in different life strategies along the geographic range of a species (Hughes 1971, Bachelet 1981, 1982, Essink et al. 1991, Sola 1997, Clarke 2003, Rodríguez-Rúa et al. 2003).

Studying the variation in population dynamics and strategies along a latitudinal gradient is a good approach to increase our knowledge of a species throughout its biogeographic range. A thorough review of previous studies on Scrobicularia plana along a wide range of its distribution, from the UK and the Wadden Sea $\left(\sim 55^{\circ} \mathrm{N}\right)$ to Southern Europe and the Mediterranean $\left(\sim 36^{\circ} \mathrm{N}\right)$, may allow us to assess distinct ecological patterns for different populations of this species.

The main goals of the present study were to analyse differences in (1) reproduction periods, (2) population dynamics, (3) growth rates and (4) secondary production of Scrobicularia plana, by comparing these results among populations along a latitudinal gradient and to assess possible relationships between latitude and $S$. plana's ecological patterns and strategies. We expect to be able to extract relevant information from these relationships that may be useful to other approaches on population studies, such as modelling, a useful tool to understand the dynamics and responses of a population to both natural and anthropogenic stressors, as well as to make predictions for future scenarios (Anastácio et al. 2009).

\section{MATERIALS AND METHODS}

An extended bibliographic search was done, and published data on 25 Scrobicularia plana were collected from several studies performed between 1930 and 2008 (Table 1), focusing on reproduction, population dynamics, growth and secondary production of Scrobicularia plana populations from the Western European and Mediterranean coasts, along a latitudinal gradient (56 to $36^{\circ} \mathrm{N}$ ) (Fig. 1).

Temperature data were collected from www. worldweather.org, in order to assess the existing temperature latitudinal gradient and to compare its patterns. Here, we use average monthly minimum and maximum temperature values (climate normals from 1971 to 2000) for the Wadden Sea, Ireland, UK (Wales and Cornwall), North France (Loire region), Gulf of Biscay (Gironde region, France and San Sebastian, Spain), Portugal (Coimbra, Lisbon and Alentejo), the Mediterranean (Marseille, France and Tunisia) and South Spain (Cádiz).

We found studies on the reproduction and gametogenic cycle of Scrobicularia plana from Ireland (Raleigh \& Keegan 2006), the UK (Hughes 1971, Worrall et al. 1983), France (Mouneyrac et al. 2008), Spain (Sola 1997, Rodríguez-Rúa et al. 2003) and Portugal (Paes-da-França 1956, Guerreiro 1998), which focused on gonad development, breeding cycle and recruitment. 


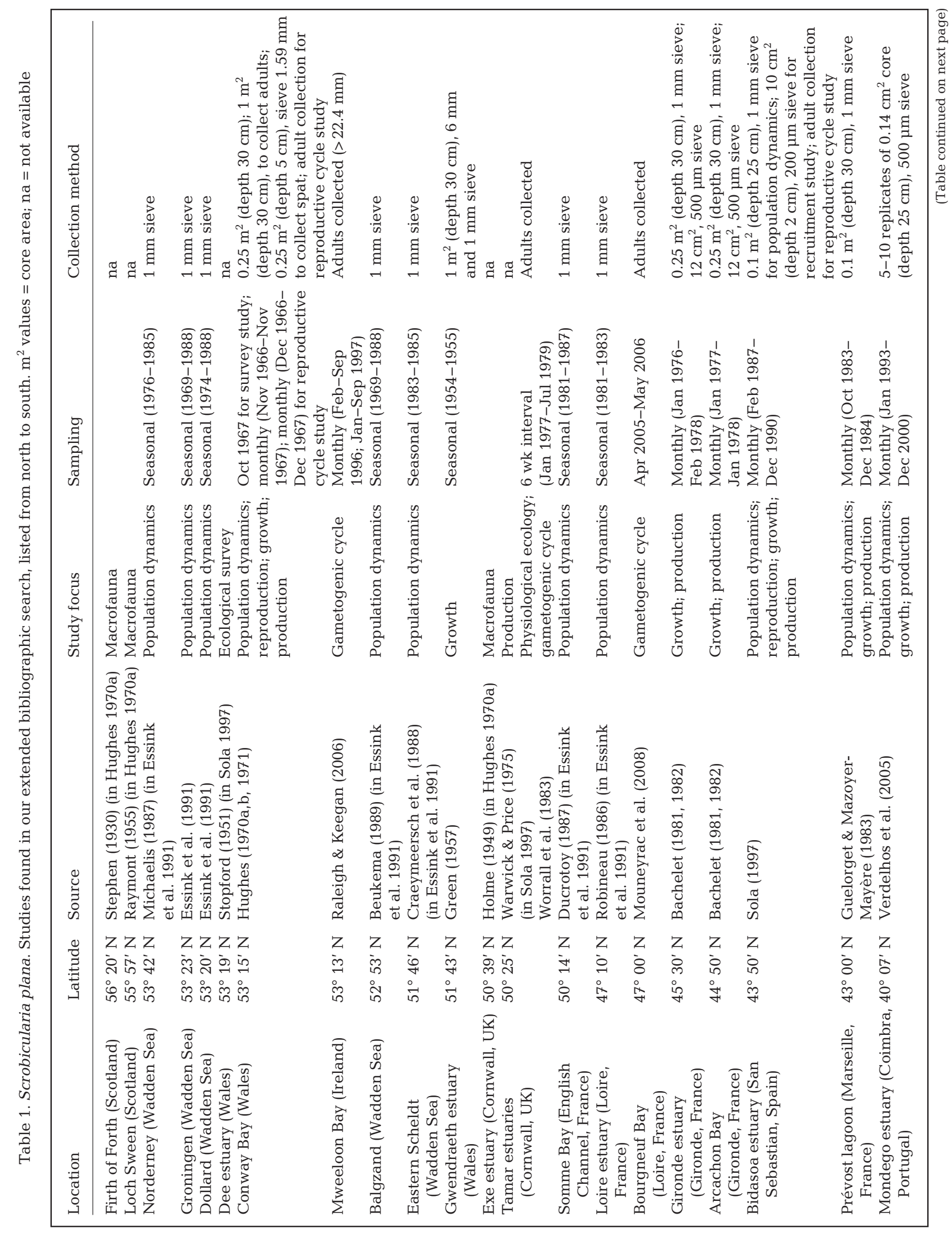



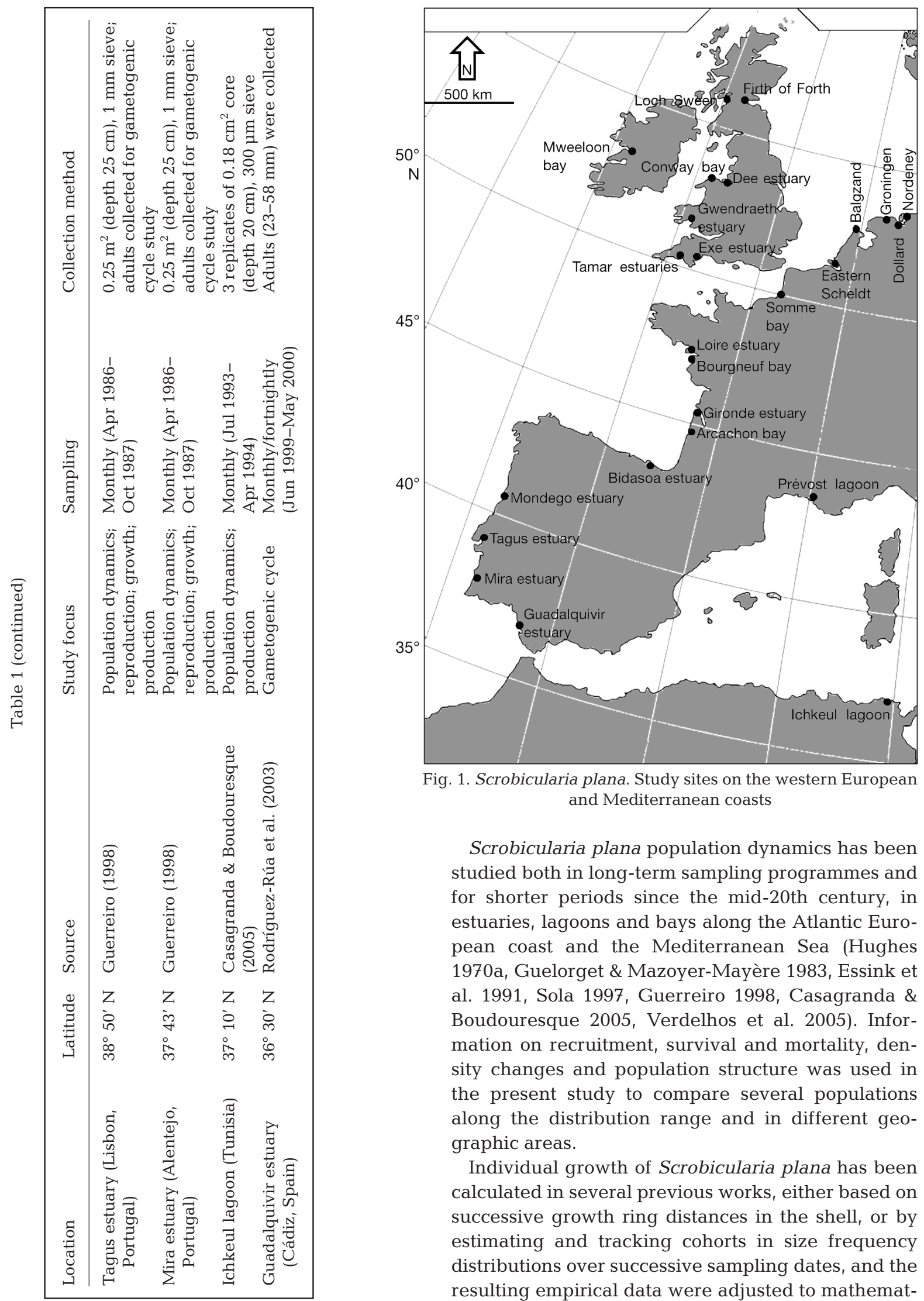

Fig. 1. Scrobicularia plana. Study sites on the western European and Mediterranean coasts

Scrobicularia plana population dynamics has been studied both in long-term sampling programmes and for shorter periods since the mid-20th century, in estuaries, lagoons and bays along the Atlantic European coast and the Mediterranean Sea (Hughes 1970a, Guelorget \& Mazoyer-Mayère 1983, Essink et al. 1991, Sola 1997, Guerreiro 1998, Casagranda \& Boudouresque 2005, Verdelhos et al. 2005). Information on recruitment, survival and mortality, density changes and population structure was used in the present study to compare several populations along the distribution range and in different geographic areas.

Individual growth of Scrobicularia plana has been calculated in several previous works, either based on successive growth ring distances in the shell, or by estimating and tracking cohorts in size frequency distributions over successive sampling dates, and the resulting empirical data were adjusted to mathemat- 
ical equations. Green (1957) estimated growth for an $S$. plana population in the Gwendraeth Estuary (Wales) based on growth rings, by constructing a curve using a series of shells. Hughes (1970a) fitted data on distances between growth rings with a FordWalford method, plotting the shell length at one winter ring $\left(L_{t}\right)$ against the shell length at the next winter ring $\left(L_{t+1}\right)$ :

$$
L_{(t+1)}=L_{t} \times\left(1-\mathrm{e}^{-k}\right)+L_{\infty} \times \mathrm{e}^{-k}
$$

where $L_{\infty}$ is the theoretical maximum size (asymptotic length), $k$ is the rate at which growth rate decreases with age and $t$ is time.

Hughes (1970a) also plotted the data from Green (1957) by the same Ford-Walford method, obtaining similar results. In the Prévost lagoon (France), growth was estimated by applying a simple mathematical model on size frequency distribution data (Guelorget \& Mazoyer-Mayère 1983). Bachelet (1981), Sola (1997) and Guerreiro (1998) used a von Bertalanffy equation to calculate $L_{t}$, based on growth rings and size frequency distributions. This equation is one of the most frequently used methods for growth estimation of molluscs, and it allows us to compare growth curves calculated for different populations:

$$
L_{t}=L_{\infty} \times\left(1-\mathrm{e}^{-k \times\left(t-t_{0}\right)}\right)
$$

where $L_{\infty}$ is asymptotic length, $t_{0}$ is the hypothetical age when $L_{t}=0$, and $k$ is the growth constant.

In the present study, we fitted data from the Mondego estuary population to the same growth model, through cohort recognition. In addition, we adjusted the von Bertalanffy model to the published results of Green (1957), Hughes (1970a) and Guelorget \& Mazoyer-Mayère (1983), calculating the parameters $k$ and $L_{\infty}$ from the Ford-Walford plot, as in Bachelet (1981). The estimated equation curves were analysed, and the parameters $\left(k, L_{\infty}\right)$ resulting from these studies were compared for different Scrobicularia plana populations along the latitudinal gradient.

Results were then analysed along the latitudinal gradient, and adjusted to mathematical equations using TableCurve 2D v. 5.01 software. Temperature and spawning data were fitted to simple regression equations: $y=a x+b$, describing a linear relationship with latitude.

Mean population abundance and individual length at Year 2 were fitted to a Gaussian equation, describing a normal distribution variation along latitude.

Data from different studies on secondary production of Scrobicularia plana were also analysed and compared. Different cohort-based methods were used to calculate secondary production: (1) removal summation method (Hughes 1970b, Bachelet 1982, Sola 1997, Guerreiro 1998, Casagranda \& Boudouresque 2005), where production is computed as the change in biomass from time $t$ to time $t+1$, over the cohort time period (sum of the standing stock gain) plus the mortality due to predation, among others (biomass eliminated), over the same period; (2) increment summation method (Bachelet 1982, Sola 1997, Guerreiro 1998, Verdelhos et al. 2005), where production is computed as the change in biomass from time $t$ to time $t+1$, over the cohort time period, due to the growth increases of all the members of the population; and (3) instantaneous growth method (Guerreiro 1998), where production is also derived from the growth increments of all the members of the population, which are added for the study period, but a growth rate is computed. These different methods have been assumed to provide similar evaluations of secondary production, and are among the most accurate (Dolbeth et al. 2005). Results from Hughes (1970b) were converted from calories to grams, and results in dry weight (DW) in Guelorget \& MazoyerMayère (1983) were converted to ash-free dry weight (AFDW) by Bachelet (1982).

A redundancy analysis (RDA) was applied to the collected and estimated data, in order to evaluate the relationships between Scrobicularia plana population dynamics, reproduction and growth parameters, the environmental parameters and latitude. The RDA was chosen after detecting a linear gradient with a detrended correspondence analysis (DCA) performed with the biotic data. All environmental variables were used in a first analysis and their significance was tested with the model forward-selection procedure. A second analysis was performed only with the significant environmental variables. These analyses were performed using CANOCO software (Van den Brink \& Ter Braak 1999).

\section{RESULTS}

Average monthly temperatures followed the characteristic seasonal pattern of temperate regions, with lower values during winter and increasing towards summer (Fig. 2). A general latitudinal gradient along the European coast and a strong relationship between temperature and latitude were observed (Fig. 3). Northern regions (e.g. Wadden Sea, Ireland and UK) are usually characterised by low temperature values, severe cold winters and mild summers, while with decreasing latitude, temperature increases and southern regions are characterised by 

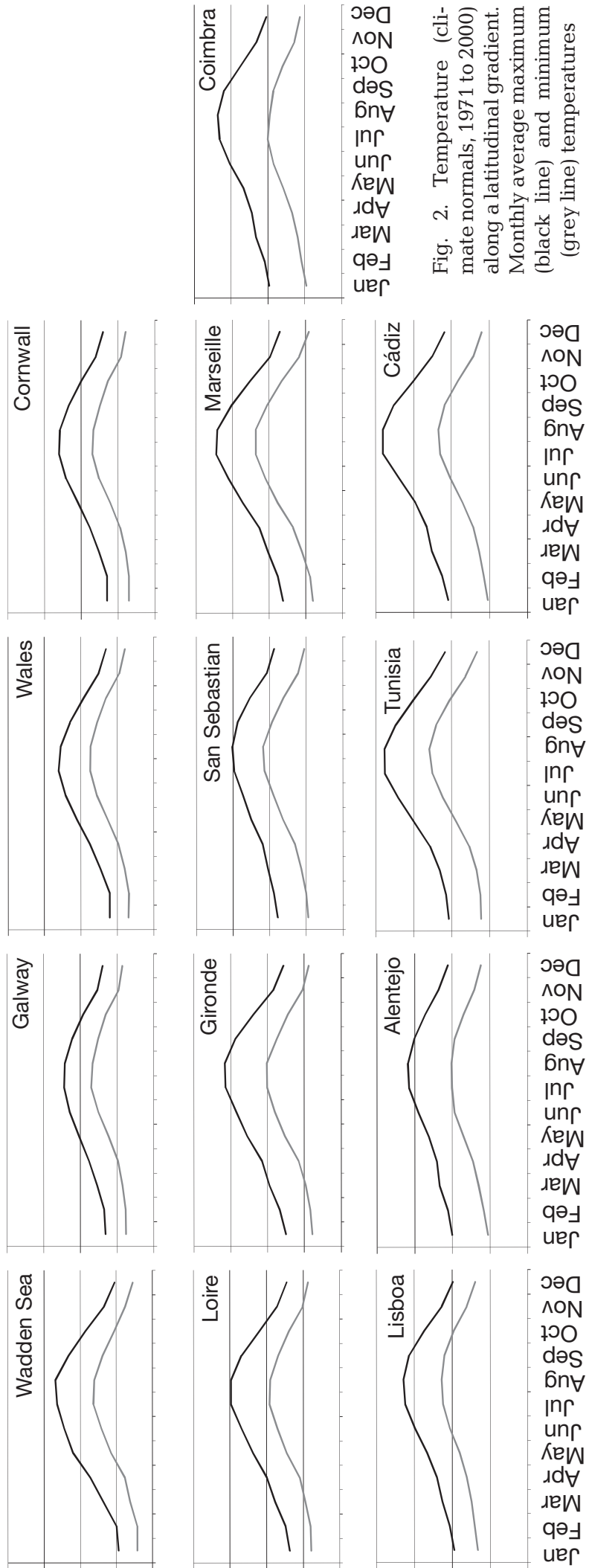

邑

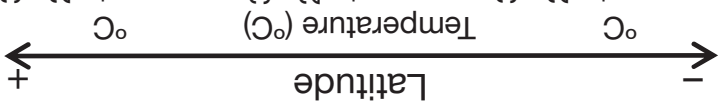

mild winters and hot summers, reaching $\sim 35^{\circ} \mathrm{C}$ in Tunisia and Cádiz (Spain) (Fig. 2).

Different reproduction patterns along latitude seem quite clear when analysing gonad development, spawning and recruitment periods for Scrobicularia plana. In northern populations, gonad development started during spring and spawning periods were usually short, lasting 2 or 3 mo during summer (vertical lines (1), (2) and (3) in Fig. 4). With decreasing latitude, gonad development showed a tendency to start earlier in the year and the same was observed for spawning periods, which increased in length towards the south to $\sim 7 \mathrm{mo}$, from March to September, in the Guadalquivir estuary (vertical line (8) in Fig. 4). Spawning period duration showed linear relationships, both with latitude and temperature (Fig. 5), increasing along a north-south gradient, to-

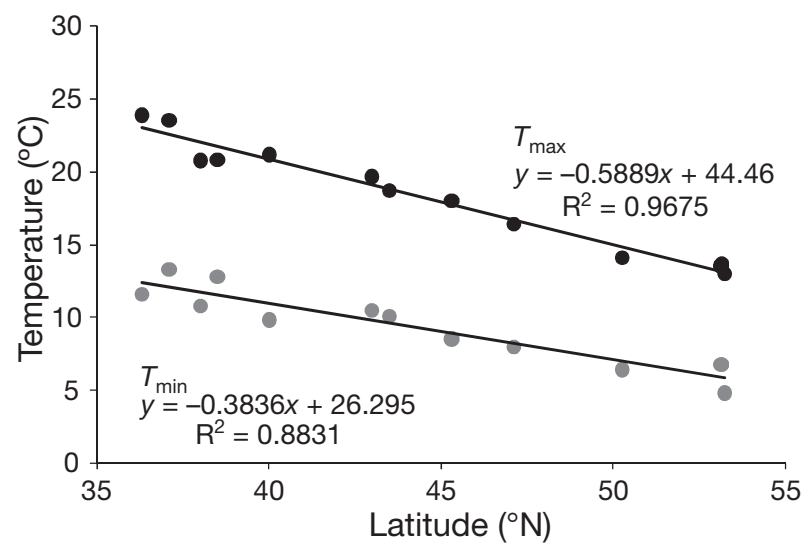

Fig. 3. Regression equations and $\mathrm{R}^{2}$ values relating latitude to monthly average maximum $\left(T_{\max }\right)$ and minimum $\left(T_{\min }\right)$ temperatures

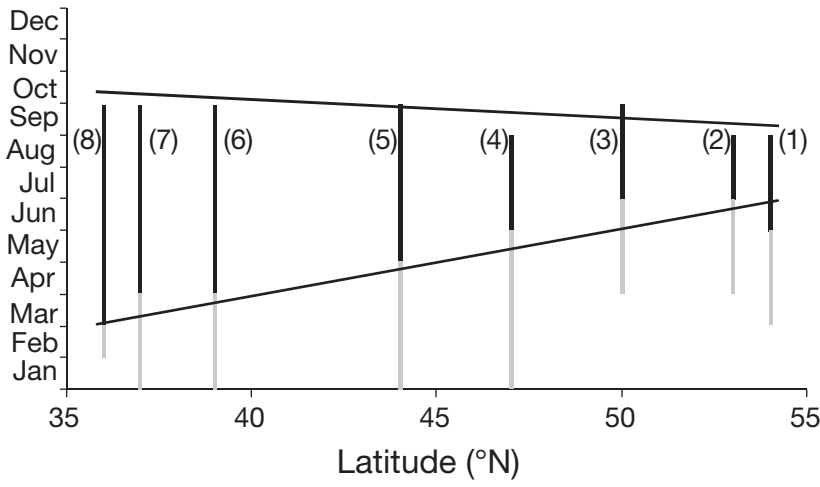

Fig. 4. Scrobicularia plana. Spawning (black vertical lines) and gonad development (grey vertical lines) periods at different latitudes: (1) Mweeloon Bay, (2) Conway Bay, (3) Tamar estuaries, (4) Bourgneuf Bay, (5) Bidasoa estuary, (6) Tagus estuary, (7) Mira estuary, (8) Guadalkivir estuary. Horizontal lines are a graphic representation of the enlargement of the spawning periods from higher latitudes towards lower latitudes 
wards warmer climates. Benthic recruitment periods were also shorter in northern populations, and increased as we looked south, where populations showed 1 large or even 2 separate shorter recruitment periods, resulting in 1 or 2 cohorts $\mathrm{yr}^{-1}$ (Table 2).

High variability of mean abundance values was observed for the studied Scrobicularia plana populations along the Western European and Mediterranean coasts (Fig. 6A). Northern populations (e.g. Wadden Sea, Ireland, UK and the French side of the English Channel) registered low abundance values, often $<250$ ind. $\mathrm{m}^{-2}$. With decreasing latitude, these values tended to increase and more abundant populations were found, particularly between 40 and $45^{\circ} \mathrm{N}\left(\sim 1000\right.$ ind. $\mathrm{m}^{-2}$ in the Gironde estuary and Arcachon Bay, 2500 ind. $\mathrm{m}^{-2}$ in the Bidasoa estuary, $\sim 3000$ ind. $\mathrm{m}^{-2}$ in the Prévost lagoon and 1500 ind. $\mathrm{m}^{-2}$ in the Mondego estuary), while further south, the mean population abundance values decreased again. S. plana's population abundance seems to follow a

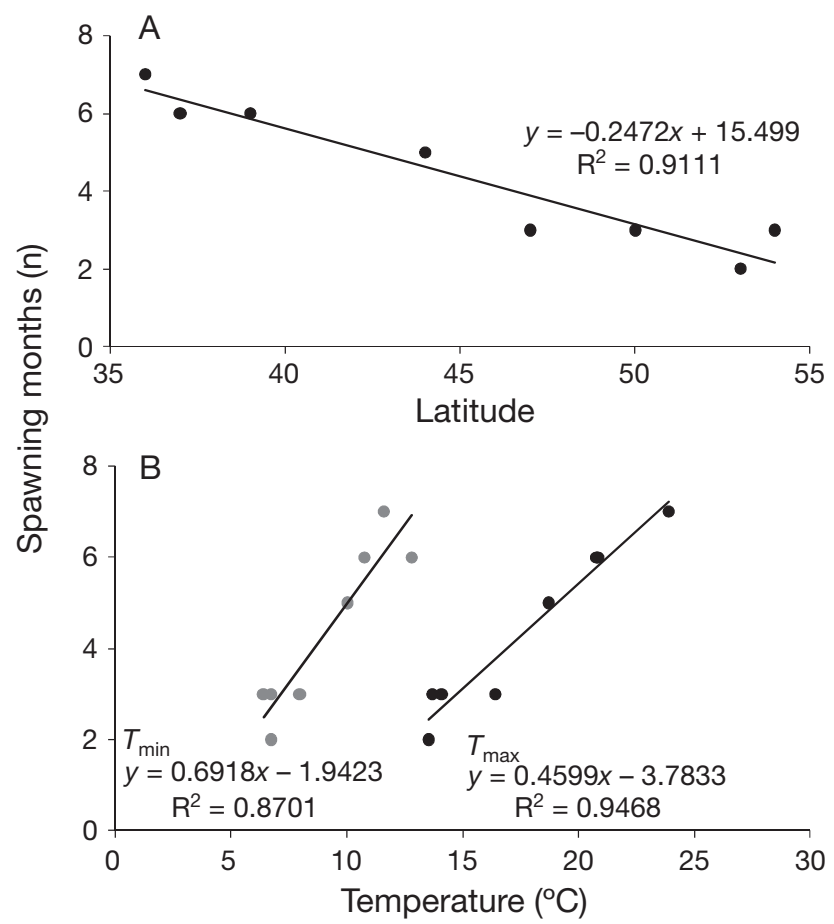

Fig. 5. Scrobicularia plana. Regression equations and $\mathrm{R}^{2}$ values relating the duration of the spawning period to (A) latitude and (B) monthly average maximum $\left(T_{\max }\right)$ and minimum $\left(T_{\min }\right)$ temperatures
Table 2. Scrobicularia plana. Benthic recruitment periods at different latitudes, listed from north to south

\begin{tabular}{|lcccc|}
\hline Location & Latitude & Cohorts & $\begin{array}{c}\text { Recruitment } \\
\text { period }\end{array}$ & Months \\
\hline Dee estuary & $53^{\circ} 19^{\prime} \mathrm{N}$ & 1 & $\begin{array}{c}\text { Summer } \\
\text { Spring }\end{array}$ & 2 \\
Gironde estuary & $45^{\circ} 30^{\prime} \mathrm{N}$ & 2 & $\begin{array}{c}\text { Summer } \\
\text { Spring }\end{array}$ & 4 \\
Arcachon Bay & $44^{\circ} 50^{\prime} \mathrm{N}$ & 2 & $\begin{array}{c}\text { Summer } \\
\text { Summer }\end{array}$ & 4 \\
Bidasoa estuary & $43^{\circ} 50^{\prime} \mathrm{N}$ & 1 & $\begin{array}{c}\text { Autumn } \\
\text { Spring }\end{array}$ & 3 \\
Prévost lagoon & $43^{\circ} 00^{\prime} \mathrm{N}$ & 1 & $\begin{array}{c}\text { Summer } \\
\text { Spring }\end{array}$ & 4 \\
Mondego estuary & $40^{\circ} 07^{\prime} \mathrm{N}$ & 2 & $\begin{array}{c}\text { Summer } \\
\text { Spring }\end{array}$ & 4 \\
Tagus estuary & $38^{\circ} 50^{\prime} \mathrm{N}$ & 2 & $\begin{array}{c}\text { Summer } \\
\text { Spring }\end{array}$ & 4 \\
Mira estuary & $37^{\circ} 43^{\prime} \mathrm{N}$ & 2 & Autumn & \\
Ichkeul lagoon & $37^{\circ} 10^{\prime} \mathrm{N}$ & 2 & &
\end{tabular}
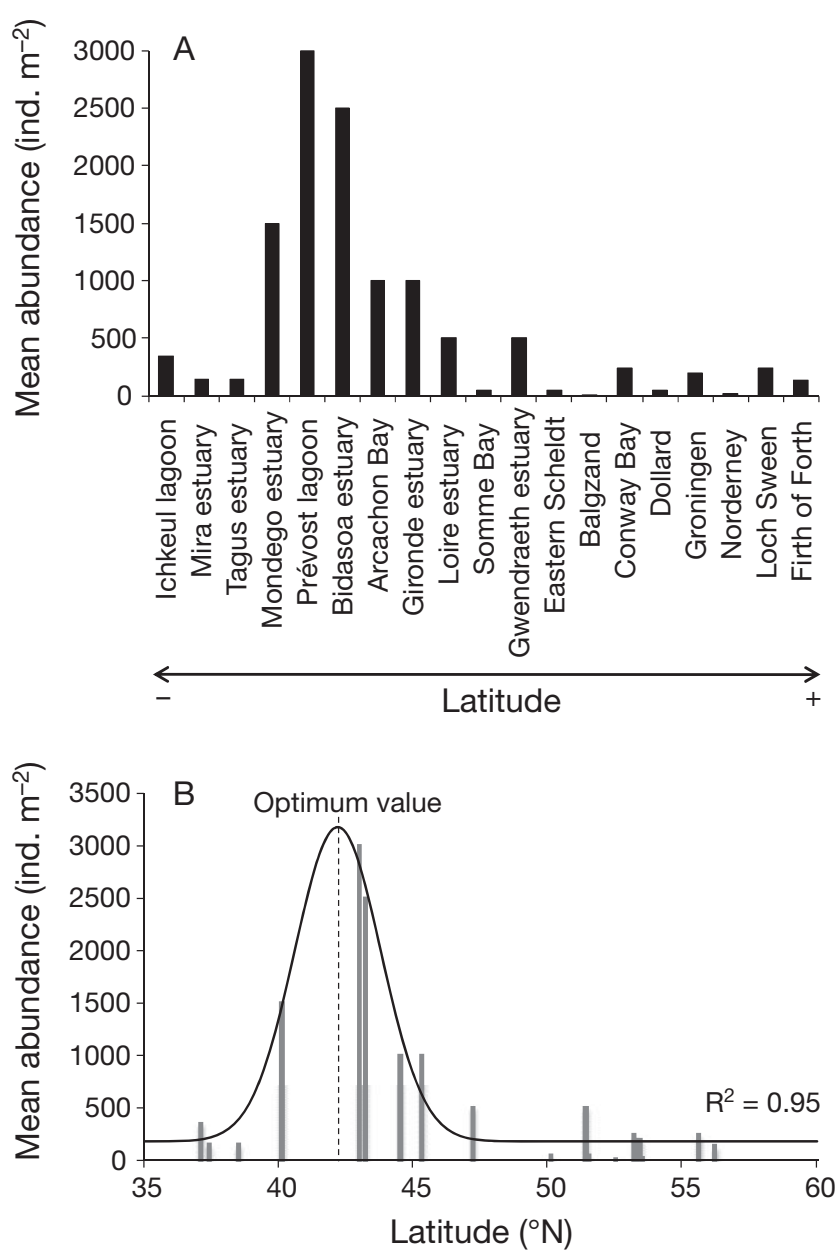

Fig. 6. Scrobicularia plana. (A) Mean population abundance and (B) the estimated Gaussian distribution along a latitudinal gradient 
Gaussian distribution along latitude (Fig. 6B) according to the equation:

$$
y=181.95+3002.24^{\left(-0.5\left[\frac{(x-42.18)}{1.6^{2}}\right]\right)}
$$

in which $y$ is abundance, and $x$ is latitude. Abundance shows maximum values near $42^{\circ} \mathrm{N}$ and decreases both towards north and south.

Analysing the estimated von Bertalanffy growth model, the resultant growth coefficient $k$ (Fig. 7) and total length at Year 1 and Year 2 (Fig. 8A), we observed different growth patterns along latitude. The 2 analysed UK populations (Conway Bay and Gwendraeth Estuary) showed similar patterns, with constant low growth: $k=0.194$ and 0.108 , respectively, reaching $\sim 10 \mathrm{~mm}$ by the first year and $\sim 20 \mathrm{~mm}$ by the second. Populations in the Gulf of Biscay showed higher $k$ values (Gironde estuary: $k=0.625$; Arcachon Bay: $k=0.322$; Bidasoa estuary: $k=0.815$ ) and an accentuated growth especially during the first and second years, reaching $\sim 18 \mathrm{~mm}$ and $\sim 28 \mathrm{~mm}$, respectively. On the Mediterranean (Prévost lagoon), growth was particularly intense, reaching $22 \mathrm{~mm}$ during the first year and $33 \mathrm{~mm}$ in the second (Fig. 8A).
For the Portuguese populations, growth was more intense during the first and second years, reaching $\sim 22 \mathrm{~mm}$, and growing $\sim 8 \mathrm{~mm}$ in the following years. Growth rates seem to be somewhat intermediate between the UK and the Gulf of Biscay and Mediterranean populations, with $k$ values between 0.2 and 0.41 . When analysing the resulting growth at Year 2 along latitude, we observed a Gaussian variation, with higher values near $43^{\circ} \mathrm{N}$ (Fig. 8B), estimated from the application of the Gauss equation:

$$
y=19.55+10.13^{\left(-0.5\left[\frac{(x-43.39)}{2.83^{2}}\right]\right)}
$$

in which $y$ is length at Year 2, and $x$ is latitude.

Production results from different studies were highly variable, either between populations of different geographic regions and even in the same area (Table 3), although from the given results, we observed highest production $(P)$ and $P / B$ ratio (where $B$ is biomass) values in areas between 40 and $45^{\circ} \mathrm{N}$, particularly in the Bidasoa estuary $\left(P=83.62 \mathrm{~g} \mathrm{~m}^{-2}\right.$ $\left.\mathrm{yr}^{-1} ; P / B=1.21 \mathrm{yr}^{-1}\right)$ and the Prévost lagoon $(P=81.05$ $\mathrm{g} \mathrm{m}^{-2} \mathrm{yr}^{-1} ; P / B=3.68 \mathrm{yr}^{-1}$ ).

Data on reproduction patterns (number of reproduction months, or NRM), mortality (Mort) and

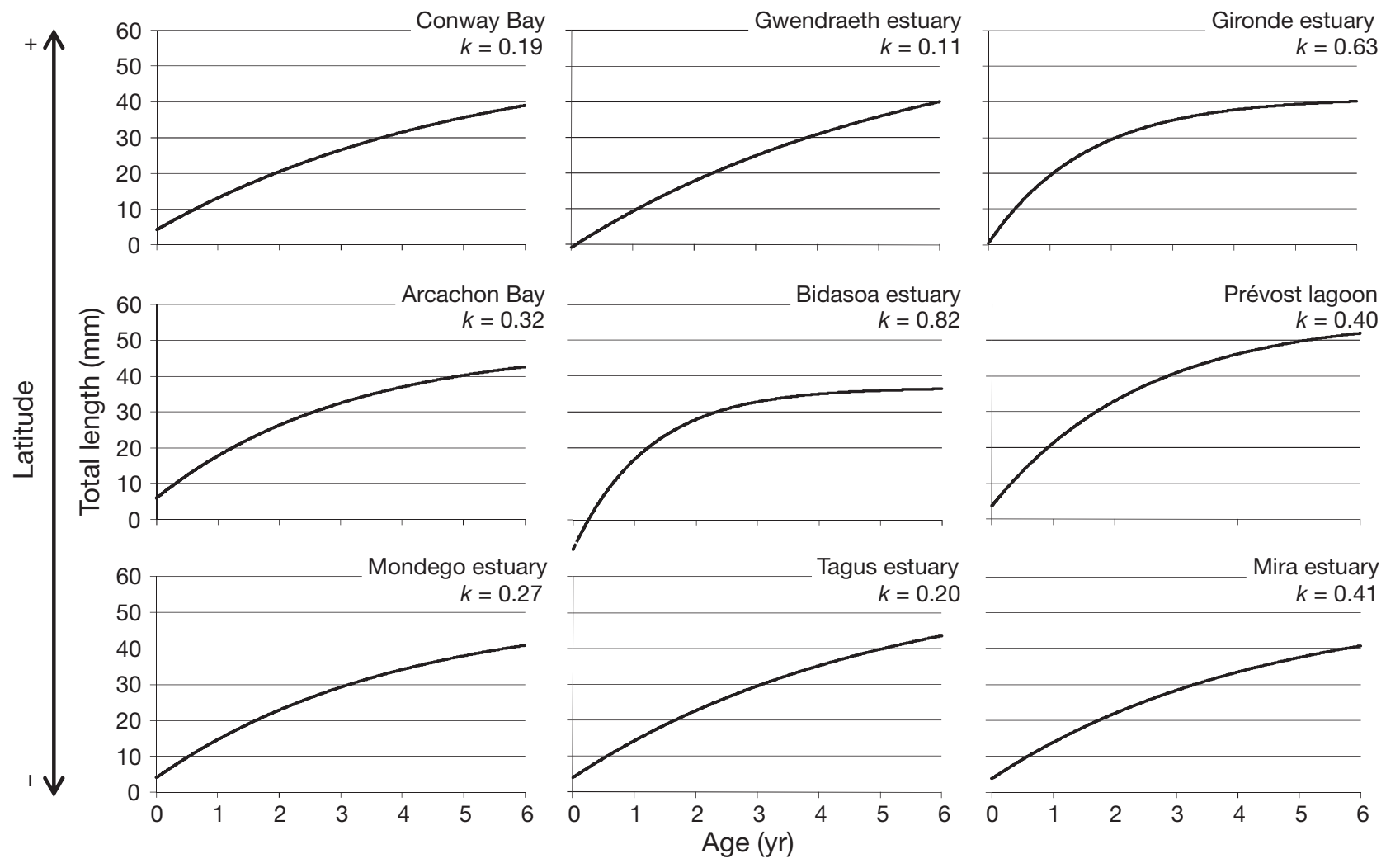

Fig. 7. Scrobicularia plana. Growth estimation (total length vs. age) using the von Bertalanffy equation on different populations along a latitudinal gradient. $k$ : growth coefficient 

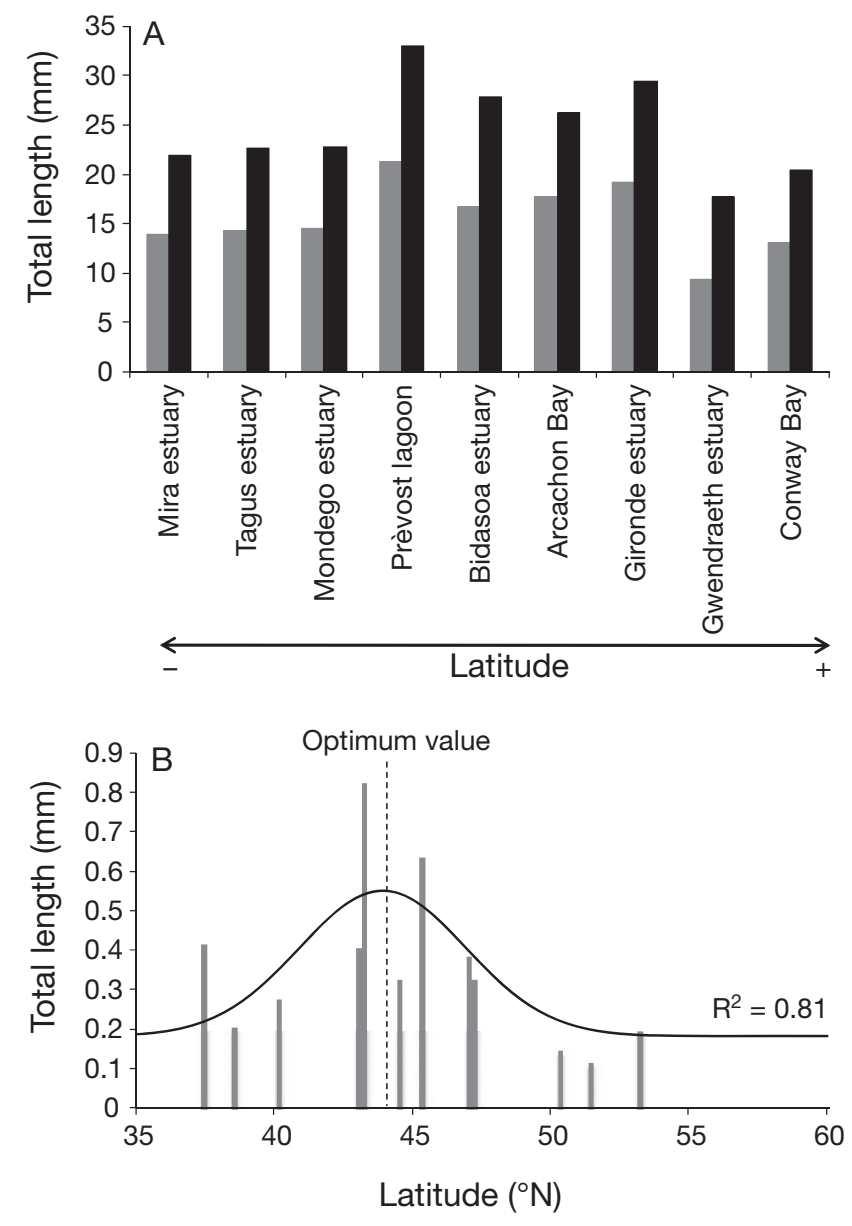

Fig. 8. Scrobicularia plana. (A) Total length at Year 1 (grey) and Year 2 (black) obtained from the von Bertalanffy growth estimation model applied to different populations, and (B) Gaussian distribution of total length at Year 2 along a latitudinal gradient growth $(k)$ were comparatively analysed using RDA, after running a DCA, in order to compare 12 Scrobicularia plana populations, relating them to temperature conditions, in order to outline the similarities of different geographic areas. A significant relationship between maximum temperature $\left(T_{\max }\right)$ and the biological variables was obtained $(\mathrm{p}<0.05)$. By analysing the resulting ordination diagram (Fig. 9), similarities among populations within the same geographic area were highlighted and populations grouped according to their characteristics.

The UK populations (Conway Bay, Gwendraeth Estuary and Tamar estuaries) form a group charac-

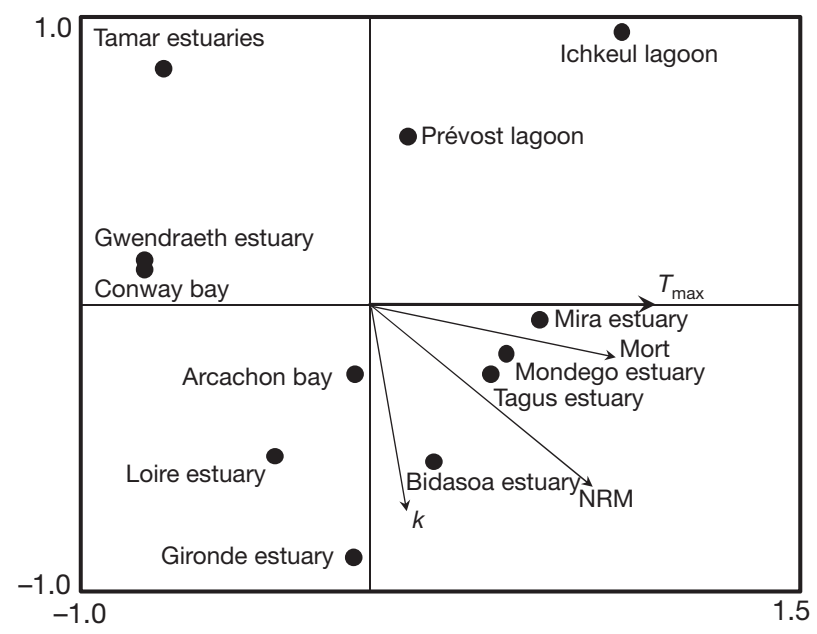

Fig. 9. Scrobicularia plana. Redundancy analysis showing relationship between monthly average maximum temperature $\left(T_{\max }\right)$, population dynamics (Mort: mortality; NRM: number of recruitment months) and growth $(k)$ patterns in the 12 populations

Table 3. Scrobicularia plana. Mean population biomass $(B)$, production $(P)$ and $P / B$ ratio for different populations along a latitudinal gradient, listed from north to south. AFDW: ash-free dry weight. na: not available

\begin{tabular}{|c|c|c|c|c|c|}
\hline Location & Latitude & Habitat & $B\left(\mathrm{~g} \mathrm{AFDW} \mathrm{m} \mathrm{m}^{-2}\right)$ & 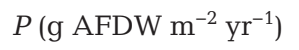 & $P / B$ ratio $\left(\mathrm{yr}^{-1}\right)$ \\
\hline \multirow[t]{2}{*}{ Conway Bay } & \multirow[t]{2}{*}{$53^{\circ} 15^{\prime} \mathrm{N}$} & Seaward & 46.24 & 13.41 & 0.29 \\
\hline & & Marshward & 4.37 & 2.97 & 0.68 \\
\hline Tamar estuaries & $50^{\circ} 25^{\prime} \mathrm{N}$ & na & 2.15 & 0.48 & 0.22 \\
\hline Arcachon Bay & $44^{\circ} 50^{\prime} \mathrm{N}$ & Interior area (fine sand) & 9.65 & 8.34 & 0.86 \\
\hline Bidasoa estuary & $43^{\circ} 22^{\prime} \mathrm{N}$ & Estuary mouth (mud) & 69.20 & 83.62 & 1.21 \\
\hline \multirow[t]{3}{*}{ Prévost lagoon } & \multirow{3}{*}{$43^{\circ} 20^{\prime} \mathrm{N}$} & Seaward (fine sand) & 22.02 & 81.05 & 3.68 \\
\hline & & Interior area (muddy sand) & 1.31 & 6.54 & 4.99 \\
\hline & & Interior area (muddy sand) & 2.04 & 4.64 & 2.28 \\
\hline Mondego estuary & $40^{\circ} 07^{\prime} \mathrm{N}$ & na & 16.17 & 9.41 & 0.58 \\
\hline Tagus estuary & $38^{\circ} 50^{\prime} \mathrm{N}$ & Interior area (marsh) & 26.10 & 6.78 & 0.26 \\
\hline \multirow[t]{3}{*}{ Mira estuary } & \multirow[t]{3}{*}{$37^{\circ} 43^{\prime} \mathrm{N}$} & Estuary mouth (sand) & 4.75 & 1.76 & 0.37 \\
\hline & & Interior area (sandy mud) & 3.74 & 0.14 & 0.04 \\
\hline & & Interior area (mud) & 7.67 & 2.40 & 0.31 \\
\hline \multirow[t]{2}{*}{ Ichkeul lagoon } & \multirow[t]{2}{*}{$37^{\circ} 10^{\prime} \mathrm{N}$} & Interior area (bare bottom) & 34.27 & 12.17 & 0.36 \\
\hline & & Channel mouth (marsh) & 22.54 & 17.41 & 0.77 \\
\hline
\end{tabular}


terised by short reproduction periods during summer, winter mortality and low $k$, reflecting low growth rates. The Gulf of Biscay (Gironde estuary, Arcachon Bay and Bidasoa estuary) populations are characterised by longer reproduction periods, summer mortality and high growth rates, forming another group. The Loire population is plotted near this group, resulting from similarities in the reproduction pattern, despite the existing differences in growth and mortality period. The Portuguese populations (Mondego estuary, Tagus estuary and Mira estuary) are grouped together, showing longer reproduction periods and summer mortality, while $k$ is smaller than in the previous group. However, $k$ values show that there are differences within this group. Finally, the Mediterranean populations (Prévost lagoon and Ichkeul lagoon) are plotted together and isolated from other groups.

\section{DISCUSSION}

Scrobicularia plana's ecological patterns are latitude-related, depending essentially on temperature, which regulates the reproductive cycle of the species and influences its survival, mortality, growth and production (Hughes 1969, 1971, Bachelet 1981, Guelorget \& Mazoyer-Mayère 1983, Worrall et al. 1983, Essink et al. 1991, Sola 1997, Rodríguez-Rúa et al. 2003, Casagranda \& Boudouresque 2005, Verdelhos et al. 2005, Raleigh \& Keegan 2006, Mouneyrac et al. 2008). However, and despite the general latitudinal gradient, temperature is also dependent on local environmental conditions. We observed similar temperature patterns for locations at different latitudes, as in the case of the Mediterranean populations (Marseille and Tunisia).

The temperature increase after the cold winter months triggers gonad development (Paes-da-França 1956, Hughes 1971, Sola 1997, Guerreiro 1998, Rodríguez-Rúa et al. 2003, Raleigh \& Keegan 2006, Mouneyrac et al. 2008) from a threshold value of $\sim 8^{\circ} \mathrm{C}$ (Hughes 1971, Sola 1997, Raleigh \& Keegan 2006) and influences its duration, lasting longer at higher latitudes and shortening towards the south.

Moreover, spawning is also dependent on temperature (Paes-da-França 1956, Hughes 1971, Sola 1997, Guerreiro 1998, Rodríguez-Rúa et al. 2003, Raleigh \& Keegan 2006, Mouneyrac et al. 2008), occurring when favourable values are observed and, as a consequence, it shows a clear latitudinal trend. Usually, it occurs later in northern populations, for short periods during summer, while further south it may start ear- lier, extending for longer time periods. In the south, spawning may show 1 or 2 main peaks, which is reflected in benthic recruitment, resulting in 1 or 2 cohorts $\mathrm{yr}^{-1}$ (Paes-da-França 1956, Hughes 1971, Sola 1997, Guerreiro 1998, Rodríguez-Rúa et al. 2003, Raleigh \& Keegan 2006, Mouneyrac et al. 2008). Similar results have been observed for Abra alba (Dauvin 1986), A. tenuis (Dekker \& Beukema 1999, Casagranda \& Boudouresque 2005) and Cerastoderma edule (Gam et al. 2010), suggesting analogous reproduction patterns for several bivalve species.

As a general trend, the most abundant Scrobicularia plana populations were found between 40 and $45^{\circ} \mathrm{N}$, near the middle of the geographic distribution of the species, decreasing towards the edges following a Gaussian distribution. This is probably a result of more frequent successful recruitments and lower mortality (Bachelet 1981, Guelorget \& MazoyerMayère 1983, Essink et al. 1991, Sola 1997, Verdelhos et al. 2005). Comparable results were registered in other bivalve species, such as Tellina tenuis (Dekker \& Beukema 1999) and Cerastoderma edule (Genelt-Yanovskiy et al. 2010). These patterns suggest that a species is more abundant near the centre of its distribution range, declining towards the edges - the abundant-centre hypothesis (Sagarin et al. 2006).

The lower abundance for northern Scrobicularia plana populations is apparently a consequence of short successful benthic recruitments, occurring only in favourable years (Green 1957, Hughes 1970a, Essink et al. 1991), and of massive mortality episodes due to harsh environmental conditions during severe winters - extreme cold, high freshwater flows and low salinity (Hughes 1970a, Essink et al. 1991).

Further south, smaller recruitment peaks were described in the Tagus and Mira estuaries (Guerreiro 1998), leading to less abundant, albeit stable and well structured, populations. Thus, smaller populations could result in lower mortality rates when compared to larger northern populations. The Mediterranean populations (Prévost and Ichkeul lagoons) are mainly dominated by juveniles, depending on successful recruitments, which are much higher in the Prévost lagoon, leading to higher density populations (Guelorget \& Mazoyer-Mayère 1983, Casagranda \& Boudouresque 2005).

Several methods have been used for Scrobicularia plana growth estimation, and in the present study we fitted the available data to a von Bertalanffy growth model, using the same method as Bachelet (1981), in order to compare growth rates for diverse populations. However, care must be taken when analysing 
and comparing different populations, since the resulting $k$ value (Bachelet 1981) is merely growth coefficient and should not be regarded as a growth rate per se (MacDonald \& Thompson 1988). In fact, the highest growth rate was observed in the Prévost lagoon (France), with individuals growing up to 33 $\mathrm{mm}$ in the second year, although the resulting $k$ (0.404) was lower than in other populations.

Temperature influences the start and end of the growing season, which is longer at decreasing latitudes, and consequently the annual length increments are usually smaller at higher latitudes (Beukema et al. 1985, Beukema \& Desprez 1986, Dauvin 1986). However, growth in Scrobicularia plana appears to follow a non-linear latitudinal gradient, but has a tendency to decrease towards its northern and southern distribution limits, showing a Gaussian distribution, with higher values between 40 and $45^{\circ} \mathrm{N}$. This pattern was also observed for Tellina tenuis (Dekker \& Beukema 1999), which showed higher growth near $51^{\circ} \mathrm{N}$, decreasing towards the north and south.

Production and productivity estimates of a population are good evaluation methods of the functional importance of a species in the ecosystem (Bachelet 1982, Casagranda \& Boudouresque 2005). Production is dependent on habitat conditions, population structure, stability and growth rates, being also highly influenced by sampling and estimation methods (Bachelet 1982, Sola 1997, Guerreiro 1998, Casagranda \& Boudouresque 2005, Verdelhos et al. 2005). Therefore, high variability is often observed between populations and even for different sampling stations of the same ecosystem (Verdelhos et al. 2005), as in other bivalve species (Dauvin 1986, Casagranda \& Boudouresque 2005).

The highest production values for Scrobicularia plana were obtained in the Bidasoa estuary and the Prévost lagoon, which may be related to both high recruitment success and growth of the species in those locations. On the other hand, exceptionally high $P / B$ ratios were observed in the Prévost lagoon, in accordance with the high growth rates and shorter lifespan found in the lagoon (Guelorget \& MazoyerMayère 1983). Productivity is a measurement of the biomass renewal rate of the population (Bachelet 1982) and shows high intraspecific variability, related to the species' biological cycle on different locations, and usually, $P / B$ ratio values tend to decrease both towards northern or southern latitudes.

Scrobicularia plana seems to show different life strategies along its distributional range, reflected in reproduction patterns, population abundance and dynamics, growth, and production. Throughout the distribution range, diverse populations have to face different habitats, resulting from the interaction of environmental variables, both dependent on latitudinal gradient and on local environmental conditions, that define its main characteristics (e.g. temperature and precipitation regimes, food availability, sediment) (Sola 1997).

Populations in latitudes between 40 and $45^{\circ} \mathrm{N}$ seem to have the highest ecological performance for this species, showing extremely successful recruitment and the highest abundance values, growth rates, production and productivity. The ecological conditions in these areas appear to be optimal for this species, with less climatic extremes of temperature and precipitation, and propitious temperature regimes for gonadal development and growth, favouring highly energetic life patterns (Clarke 2003, Sagarin et al. 2006).

In contrast, populations further north and south show 'slower' life strategies, with less successful recruitment, lower abundance, significant mortality episodes and lower growth and productivity. This is certainly a result of poorer ecological conditions in areas closer to the edges of the species' geographic distribution. In fact, animals living at the biogeographic limits of the species' distribution are assumed to live on the limits of their adaptation capacities, showing poorer ecological performance and higher sensitivity to stress, when compared to animals living at the centre of its distribution (Hummel et al. 1998, Sagarin et al. 2006, Beukema et al. 2009).

The present study is a review of published research on Scrobicularia plana along a latitudinal gradient, with further analysis of those studies' results. One of the main problems inherent to this type of study is the extensive bibliographic research required, in order to gather a comprehensive data set to allow a robust analysis. In this review, the main limitation was the need to use published data and results, facing the impossibility of using the raw data from the referred studies.

However, a thorough review and comparison were performed and with the analysis of Scrobicularia plana ecological patterns, throughout part of its distribution range, important results were achieved. Most latitudinal-gradient studies provide a powerful tool that can be used to understand temperaturedependent ecological patterns, as well as to predict adaptive tolerance and responses to climate change (Jansen et al. 2007).

Major impacts are expected on populations living on the edges of their geographic distribution, affect- 
ing abundance and population dynamics and even causing shifts to distribution limits of a species (Dekker \& Beukema 1999, Jansen et al. 2007, Beukema et al. 2009). Moreover, with increasing climate change, variations in temperature patterns are expected, altering both the latitudinal gradient and seasonality. This may lead to significant changes in the population dynamics throughout its geographic range, as already observed for Mytilus sp. and Macoma balthica (Jansen et al. 2007, Beukema et al. 2009). Furthermore, increased knowledge of the ecological patterns and life strategies is achieved with this kind of study, which may be useful to future approaches to Scrobicularia plana ecology assessment.

Acknowledgements. This work was supported by FCT (Fundação para a Ciência e Tecnologia) through a PhD Grant attributed to Tiago Cardoso (SFRH/BD/19812/2004).

\section{LITERATURE CITED}

Anastácio PM, Verdelhos T, Marques JC, Pardal MA (2009) A validated population-dynamics model for Scrobicularia plana (Mollusca, Bivalvia) in a south-western European estuary. Mar Freshw Res 60:404-416

Angilletta MJ, Sears MW (2004) Evolution of thermal reaction norms for growth rate and body size in ectotherms: an introduction to the symposium. Integr Comp Biol 44: 401-402

Bachelet G (1981) Application de l'équation de von Bertalanffy a la croissance du bivalve Scrobicularia plana. Cah Biol Mar 22:291-311

Bachelet G (1982) Quelques problèmes lies à l'estimation de la production secondaire. Cas des bivalves Macoma balthica et Scrobicularia plana. Oceanol Acta 5:421-431

Beukema JJ, Desprez M (1986) Single and dual annual growing seasons in the tellinid bivalve Macoma balthica (L.). J Exp Mar Biol Ecol 102:35-45

- Beukema JJ, Knol E, Cadée GC (1985) Effects of temperature on the length of the annual growing season in the tellinid bivalve Macoma balthica (L.) living on tidal flats in the Dutch Wadden Sea. J Exp Mar Biol Ecol 90: 129-144

> Beukema JJ, Dekker R, Jansen JM (2009) Some like it cold: populations of the tellinid bivalve Macoma balthica (L.) suffer in various ways from a warming climate. Mar Ecol Prog Ser 384:135-145

> Cardoso PG, Raffaelli D, Pardal MA (2008) The impact of extreme weather events on the seagrass Zostera noltii and related Hydrobia ulvae population. Mar Pollut Bull 56:483-492

> Casagranda C, Boudouresque CF (2005) Abundance, population structure and production of Scrobicularia plana and Abra tenuis (Bivalvia: Scrobicularidae) in a Mediterranean brackish lagoon, Lake Ichkeul, Tunisia. Int Rev Hydrobiol 90:376-391

> Clarke A (2003) Costs and consequences of evolutionary temperature adaptation. Trends Ecol Evol 18:573-581
Crame JA (2000) Evolution of taxonomic diversity gradients in the marine realm: evidence from the composition of Recent bivalve faunas. Paleobiology 26:188-214

> Crame JA (2002) Evolution of taxonomic diversity gradients in the marine realm: a comparison of Late Jurassic and Recent bivalve faunas. Paleobiology 28:184-207

> Dauvin J (1986) Biologie, dynamique et production d'une population d'Abra alba (Wood) (Mollusque-Bivalve) de la baie de Morlaix (Manche occidentale). J Exp Mar Biol Ecol 97:151-180

Dekker R, Beukema JJ (1999) Relations of summer and winter temperatures with dynamics and growth of two bivalves, Tellina tenuis and Abra tenuis, on the northern edge of their intertidal distribution. J Sea Res 42:207-220

> Dolbeth M, Lillebø AI, Cardoso P, Ferreira S, Pardal MA (2005) Annual production of estuarine fauna in different environmental conditions: an evaluation of the estimation methods. J Exp Mar Biol Ecol 326:115-127

Essink K, Beukema JJ, Coosen J, Craeymeersch JA, Ducrotoy JP, Michaelis H, Robineau B (1991) Population dynamics of the bivalve mollusc Scrobicularia plana (da Costa): comparisons in time and space. In: Elliott $M$, Ducrotoy JP (eds) Estuaries and coasts: spatial and temporal intercomparisons. Olsen \& Olsen, Fredensborg, p $167-172$

Gam M, de Montaudouin X, Bazairi H (2010) Population dynamics and secondary production of the cockle Cerastoderma edule: a comparison between Merja Zerga (Moroccan Atlantic Coast) and Arcachon Bay (French Atlantic Coast). J Sea Res 63:191-201

> Genelt-Yanovskiy E, Poloskin A, Granovitch A, Nazarova S, Strelkov P (2010) Population structure and growth rates at biogeographic extremes: a case study of the common cockle, Cerastoderma edule (L.) in the Barents Sea. Mar Pollut Bull 61:247-253

> Giangrande A, Licciano M (2004) Factors influencing latitudinal pattern of biodiversity: an example using Sabellidae (Annelida, Polychaeta). Biodivers Conserv 13: 1633-1646

Green J (1957) The growth of Scrobicularia plana (da Costa) in the Gwendraeth estuary. J Mar Biol Assoc UK 36:41-47

Guelorget O, Mazoyer-Mayère C (1983) Croissance, biomasse et production de Scrobicularia plana dans une lagune méditerranéenne: l'étang du Prévost à Palavas (Hérault, France). Vie Mar 5:12-22

Guerreiro J (1998) Growth and production of the bivalve Scrobicularia plana in two southern European estuaries. Vie Milieu 48:121-131

Hughes RN (1969) A study of feeding in Scrobicularia plana. J Mar Biol Assoc UK 49:805-823

Hughes RN (1970a) An energy budget for a tidal flat population of the bivalve Scrobicularia plana (da Costa). J Anim Ecol 39:357-381

Hughes RN (1970b) Population dynamics of the bivalve Scrobicularia plana (da Costa) on an intertidal mud flat in North Wales. J Anim Ecol 39:333-356

Hughes RN (1971) Reproduction of Scrobicularia plana, da Costa (Pelecypoda: Semelidae) in North Wales. Veliger 14:77-81

Hummel R, Bogaardsa R, Bekb T, Polishchukb L and others (1998) Growth in the bivalve Macoma balthica from its northern to its southern distribution limit: a discontinuity in North Europe because of genetic adaptations in Arctic populations? Comp Biochem Physiol A 120:133-141

Jansen JM, Pronker AE, Kube S, Sokolowski A and others 
(2007) Geographic and seasonal patterns and limits on the adaptive response to temperature of European Mytilus spp. and Macoma balthica populations. Oecologia 154:23-34

Langston WJ, Burt GR, Chesman BS (2007) Feminisation of male clams Scrobicularia plana from estuaries in Southwest UK and its induction by endocrine-disrupting chemicals. Mar Ecol Prog Ser 333:173-184

MacDonald BA, Thompson RJ (1988) Intraspecific variation in growth and reproduction on latitudinally differentiated populations of the giant scallop Placopecten magellanicus (Gmelin). Biol Bull (Woods Hole) 175:361-371

Macpherson E (2002) Large-scale species-richness gradients in the Atlantic Ocean. Proc R Soc B Biol Sci 269: $1715-1720$

Mouneyrac C, Linot S, Amiard JC, Amiard-Triquet C and others (2008) Biological indices, energy reserves, steroid hormones and sexual maturity in the infaunal bivalve Scrobicularia plana from three sites differing by their level of contamination. Gen Comp Endocrinol 157: 133-141

Paes-da-França ML (1956) Variação sazonal das gónadas em Scrobicularia plana da Costa. Arq Mus Bocage 27: 107-130

Raleigh J, Keegan BF (2006) The gametogenic cycle of Scrobicularia plana (Mollusca: Bivalvia) in Mweeloon Bay (Galway, west coast of Ireland). J Mar Biol Assoc UK 86: 1157-1162

Rex MA, Stuart CT, Coyne G (2000) Latitudinal gradients of species richness in the deep-sea benthos of the North Atlantic. Proc Natl Acad Sci USA 97:4082-4085

Rodríguez-Rúa A, Prado MA, Romero Z, Bruzon M (2003)

Editorial responsibility: Hans Heinrich Janssen, Oldendorf/Luhe, Germany
The gametogenic cycle of Scrobicularia plana (da Costa, 1778) (Mollusc: Bivalve) in Guadalquivir estuary (Cadiz, SW Spain). Aquaculture 217:157-166

> Roy K, Jablonski D, Valentine JW (2000a) Dissecting latitudinal diversity gradients: functional groups and clades of marine bivalves. Proc R Soc B Biol Sci 267:293-299

> Roy K, Jablonski D, Martien KK (2000b) Invariant sizefrequency distributions along a latitudinal gradient in marine bivalves. Proc Natl Acad Sci USA 97: 13150-13155

Sagarin RD, Gaines SD, Gaylord B (2006) Moving beyond assumptions to understand abundance distributions across the ranges of species. Trends Ecol Evol 21: 524-530

> Sola JC (1997) Reproduction, population dynamics growth and production of Scrobicularia plana da Costa (Pelecypoda) in the Bidasoa estuary, Spain. Neth J Aquat Ecol 30:283-296

Van den Brink PJ, Ter Braak CJF (1999) Principal response curves: analysis of time-dependent multivariate responses of a biological community to stress. Environ Toxicol Chem 18:138-148

> Verdelhos T, Neto JM, Marques JC, Pardal MA (2005) The effect of eutrophication and coastal management on the bivalve Scrobicularia plana. Estuar Coast Shelf Sci 63: 261-268

> Willig MR, Kaufman DM, Stevens RD (2003) Latitudinal gradients of biodiversity: pattern, process, scale and synthesis. Annu Rev Ecol Evol Syst 34:273-309

> Worrall CM, Widdows J, Lowe DM (1983) Physiological ecology of three populations of the bivalve Scrobicularia plana. Mar Ecol Prog Ser 12:267-279

Submitted: June 7, 2010; Accepted: August 23, 2011 Proofs received from author(s): November 24, 2011 